\title{
Pengunaaan Analisis Rasio dalam Pengukuran Kinerja Keuangan Perusahaan pada PT. Gudang Garam Tbk
}

\author{
Sayekti Suindah Dwiningwarni ${ }^{1}$, Judi Suharsono ${ }^{2}$, Dian Yuliana Safitri ${ }^{3}$ \\ ${ }^{13}$ Universitas Darul ‘Ulum Jombang \\ ${ }^{2}$ Universitas Panca Marga Probolinggo
}

\begin{abstract}
The motivation of this research is research (Rosini \& Gunawan 2018; B.Batchimeg 2017). In addition, the motivation of this study also continued the research of Sayekti Suindyah Dwiningwarni (1997). The purpose of this study (1) to analyze the development of corporate financial performance from solvency and profitability ratios; (2) to analyze the measurement of the company's financial performance using solvency and profitability ratios. This research uses quantitative descriptive analysis method.

The results of the study (1) the development of the company's financial performance in terms of solvency ratios experienced good development, this is indicated by the value of the solvency ratio that is getting better / better in fulfilling both short and long term obligations; (2) the development of the company's financial performance in terms of profitability ratios from experiencing good development, this is indicated by the value of the profitability ratio that is getting better / better in generating profits or profits; (3) measurement of company performance in terms of solvency ratio shows solvable conditions, meaning the assets is greater than the debt. (4) measurement of company performance in terms of profitability ratios shows good conditions, meaning the level of profits obtained from year to year has increased. This means that the company is in good financial condition and sovabel.
\end{abstract}

Keywords : development. measurement, financial ratio, solvency, profitability

Abstrak

Motivasi dari penelitian ini adalah penelitian (Rosini \& Gunawan 2018; B.Batchimeg 2017). Selain itu motivasi dari penelitian ini juga melanjutkan penelitian Sayekti Suindyah Dwiningwarni (1997). Permasalahan kinerja keuangan perusahaan adalah sebuah permasalahan yang selalu muncul dalam sebuah perusahaan. Tujuan penelitian ini (1) untuk menganalisis perkembangan kinerja keuangan perusahaan dari rasio leverage dan profitabilitas; (2) untuk menganalisis pengukuran kinerja keuangan perusahaan dengan menggunakan rasio leverage dan profitabiltas. Penelitian ini menggunakan metode analisis deskriptif kuantitatif.

Hasil penelitian(1) perkembangan kinerja keuangan perusahaan dari sisi rasio leverage mengalami perkembangan yang baik, ini ditunjukkan dengan nilai rasio solvabiltas yang semakin baik/cukup dalam pemenuhan kewajiban baik jangka pendek maupun jangka panjang; (2) perkembangan kinerja keuangan perusahaan dari sisi rasio profitabilitas dari mengalami perkembangan yang baik, ini ditunjukkan dengan nilai rasio profitabilitas yang semakin baik/cukup dalam menghasilkan keuntungan atau laba; (3) pengukuran kinerja perusahaan ditinjau dari rasio leverage menunjukkan kondisi solvabel, artinya aktiva lebih besar dari hutang. (4) pengukuran kinerja perusahaan ditinjau dari rasio profitabilitas menunjukkan kondisi yang baik, artinya tingkat keuntungan yang diperoleh dari tahun ke tahun mengalami peningkatan.Ini berarti bahwa perusahaan dalam kondisi keuangan yang baik dan sovabel.

Kata Kunci : perkembangan. pengukuran, rasio keuangan, leverage, profitabilitas

\section{PENDAHULUAN}

Ekonomi menjadi organisasi apapun; apakah dalam produksi atau jasa tergantung pada pemantauan dan pengelolaan aliran dana dalam dan di luar organisasi yang dilakukan secara terus menerus sepanjang masa. Dengan diperkenalkannya laporan arus kas sebagai bagian integral dari laporan tahunan perusahaan untuk mengganti laporan arus dana, memperkenalkan dimensi baru untuk informasi yang tersedia untuk pemegang saham terutama investor dan analis yang memanfaatkan laporan keuangan. (Amah et al.
2016). Penelitian yang dilakukan (SD Suindyah 1997) menghasilkan (1) kedelapan belas rasio keuangan yang dipakai dalam penelitian dapat digunakan untuk mengelompokan perusahaan yang berkinerja baik dan tidak baik; (2) Faktor-faktor yang berperan sebagi pembeda dalam pengelompokan perusahaan yang berkinerja baik dan tidak baik adalah EATS, TATO, WCTA, WCTO, CTD, DER, SG dan DPR; (3) Adanya perubahan jumlah perusahaan yang dikelompokkan berdasarkan kinerja PER-k dengan didasarkan analisis Diskriminan. 
Analisis keuangan adalah proses menilai posisi keuangan perusahaan dengan menganalisis stabilitas, kelangsungan hidup dan profitabilitas. Salah satu tujuan utama dari analisis keuangan adalah untuk mengenali perubahan tren keuangan, untuk membantu mengukur kemajuan yang dibuat oleh suatu perusahaan dan mengidentifikasi hubungan untuk menarik kesimpulan logis pada kinerja perusahaan. Ini adalah langkah-langkah deskriptif dan analisis posisi keuangan dan kinerja. Itu termasuk aset lancar, kewajiban lancar, total aset, pemegang saham ekuitas, total pendapatan, total beban dan laba bersih. (Sultan 2014). Laba rugi menunjukkan hasil operasi selama periode waktu tertentu dalam hal pendapatan yang diperoleh pandangan diringkas dari posisi keuangan dan operasi perusahaan. Analisis laporan keuangan adalah proses hubungan evaluasi antara bagian komponen dari laporan keuangan untuk mendapatkan yang lebih baik pemahaman posisi perusahaan dan prestasi. (Anwar et al. 2016).

Penelitian tentang pengukuran kinerja keuangan akan memberikan kontribusi berupa perluasan wawasan tentang bagaimana menjaga agar perusahaan bertahan dan berkembang sesuai dengan tuntunan kesehatan keuangan perusahaan yang dilihat dari berbagai rasio keuangan (Anwar et al. 2016). Permasalahan dalam penelitian ini (1) Bagaimana perkembangan kinerja keuangan ditinjau dari rasio leverage dan profitabilitas pada tahun 2014-2017; (2) Bagaimana pengukuran kinerja keuangan perusahaan diukur dengan rasio leverage dan profitabilitas dari tahun 2014-2017. Tujuan penelitian (1) untuk menganalisis perkembangan kinerja keuangan perusahaan dari rasio leverage dan profitabilitas; (2) untuk menganalisis pengukuran kinerja keuangan perusahaan dengan menggunakan rasio leverage dan profitabiltas.

\section{KAJIAN LITERATUR}

\section{Kinerja Keuangan}

Kinerja keuangan adalah suatu analisa kesehatan keuangan perusahaan yang dilakukan untuk melihat suatu perusahaan telah melaksanakan dan menggunakan aturan pelaksanaan keuangan secara baik dan benar, contohnya membuat laporan keuangan yang telah memenuhi standar dan ketentuan dalam SAK (Standar Akuntansi Keuangan), GAAP (Generally Accepted Accounting Principles), atau yang lainnya (Rosini \& Gunawan 2018). Kinerja keuangan adalah suatu capaian hasil atau prestasi yang telah diperoleh oleh manajemen perusahaan dalam menjalankan fungsinya mengelola aset perusahaan secara efektif selama periode tertentu (Riyashad Ahmed 2001). Bagi perusahaan kinerja keuangan sangat dibutuhkan untuk mengetahui dan mengevaluasi tingkat keberhasilan perusahaan berdasarkan aktivitas keuangan yang telah dilaksanakan. Dari berbagai pengertian tersebut, dapat disimpulkan bahwa kinerja keuangan adalah kemampuan perusahaan dalam pencapaian prestasi perusahaan pada suatu periode waktu tertentu yang memberikan gambaran tentang kesehatan keuangan perusahaan dengan alat ukur solvabilitas, aktivitas, likuiditas dan profitabilitas.

\section{Pengukuran Kinerja Keuangan}

Pengukuran kinerja keuangan dilakukan melalui Rasio keuangan merupakan suatu cara yang membuat perbandingan data keuangan perusahaan menjadi lebih berarti. Rasio keuangan menjadi dasar untuk menjawab beberapa pertanyaan penting mengenai kesehatan keuangan dari perusahaan. Pertanyaan tersebut dapat meliputi likuditas perusahaan, kemampuan manajemen memperoleh laba dari penggunaan aktiva perusahaan, dan kemampuan manajemen mendanai investasinya, serta hasil yang dapat diperoleh para pemegang saham dari investasi yang dilakukannya ke dalam perusahaan.

Salah satu alat pengukuran kinerja keuangan adalah analisis rasio keuangan. Analisis rasio keuangan adalah pengukuran kinerja yang dilakukan dengan menggunakan rasio keuangan. Analisis rasio keuangan dilakukan dengan cara membuat laporan keuangan dasar yaitu neraca (balancesheet), perhitungan rugi laba (income statement), dan laporan arus kas (cash flow statement). Hasil penghitungan rasio keuangan menjadi lebih jelas jika dihubungan dengan pola historis perusahaan, yang dilihat adalah perhitungan pada sejumlah tahun guna menentukan apakah perusahaan dalam kondisi baik atau sebaliknya memburuk, atau melakukan perbandingan dengan perusahaan lain dalam industri yang sama (B.Batchimeg 2017). Macam-macam rasio keuangan yang digunakan dalam mengukur kinerja keuangan, antara lain (1) Rasio profitabilitas; (2) Rasio Leverage; (3) Rasio Aktivitas; (4) Rasio Likuiditas. Penelitian ini menggunakan dua rasio keuangan dalam mengukur kinerja keuangan perusahaan, yaitu:

1. Rasio Leverage, artinya rasio yang digunakan untuk mengukur kemampuan suatu perusahaan untuk membayar seluruh hutang (baik jangka pendek maupun jangka panjang). Suatu perusahaan yang mampu membayar hutangnya berarti bahwa perusahaan tersebut mempunyai aktiva atau kekayaan yang cukup untuk membayar seluruh hutangnya, tetapi tidak dengan sendirinya berarti bahwa perusahaan tersebut dikatakan lancar atau likuid. Sebaliknya perusahaan yang insolvabel (tidak solvabel) berarti bahwa perusahaan tersebut adalah tidak likuid. Leverage adalah kemampuan suatu perusahaan dalam memenuhi kewajibannya dalam membayar hutang secara tepat waktu. 
Rasio leverage yang digunakan, adalah Debt Asset Ratio (DAR), dengan rumus:

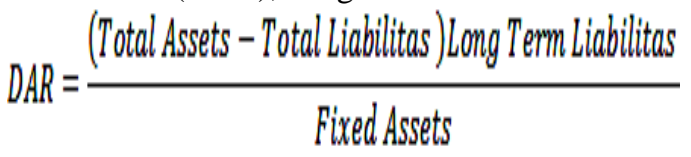

2. Rasio Profitabilitas, artinya rasio yang digunakan untuk mengukur efektivitas manajemen secara keseluruhan yang ditunjukan oleh besar kecilnya tingkat keuntungan yang diperoleh dalam hubungannya dengan penjualan maupun investasi. Semakin baik rasio profitabilitas maka semakin baik menggambarkan kemampuan tingginya perolehan keuntungan perusahaan. Rasio profitabilitas yang digunakan antara lain:

a) Return On Investment (ROI), yaitu rasio yang digunakan untuk mengukur sejauh mana investasi yang telah ditanamkan mampu memberikan pengembalian keuntungan sesuai dengan yang diharapkan. Dan investasi tersebut sebenarnya sama dengan asset perusahaan yang ditanamkan atau ditempatkan. Rumus ROI :

$$
R O I=\frac{\text { Earning After Tax }(E A T)}{\text { Total asset }}
$$

b) Net Profit Margin (NPM), yaitu rasio antara laba bersih (net profit) dengan penjualan (sales). Rasio ini untuk mengukur besarnya laba bersih yang dicapai oleh perusahaan dari sejumlah penjualan yang telah dilakukan. Rumus NPM:

$$
\text { Net Profit }=\frac{\text { Laba Bersih Setelah Pajak }}{\text { Penjualan }} \times 100 \%
$$

c) Return on Equity (ROE). yaitu rasio yng digunakan untuk mengukur sejauh mana suatu perusahaan mempergunakan sumber daya yang dimiliki untuk mampu memberikan laba atas ekuitas. Rumus ROE:

$$
\text { ROE }=\frac{\text { Earning After } \operatorname{Tax}(E A T)}{\text { Shareholder's Equity }}
$$

Renáta Myšková (2017) melakukan penelitian dengan hasil yang menunjukkan bahwa perusahaan yang memiliki hasil keuangan secara verbal tersebut memberikan gambaran tidak hanya nilai-nilai yang dicapai dengan indikator keuangan saja yang menunjukkan hasil yang baik, tetapi juga menguraikan penyebab tercapainya hasil secara lebih rinci. (Ganga et al. 2015) meneliti tentang evaluasi kinerja keuangan perusahaan dengan hasil penelitiannya menunjukkan bahwa rasio keuangan saat ini, yaitu tahun 2011-2012 sangat tinggi dibandingkan dengan masa empat tahun yang lalu. Semakin tinggi Current Ratio, semakin tinggi jumlah aktiva lancar yang tersedia dibandingkan dengan jumlah kewajiban saat ini. (B.Batchimeg
2017) melakukan penelitian dengan hasil pertumbuhan penjualan, laba per saham dan biaya berpengaruh positif teradap kinera keuangan suatu organisasi oleh ROS, sementara pengembalian biaya memiliki efek positif pada kinerja keuangan. (Amah et al. 2016) melakukan penelitian dengan hasil menunjukkan bahwa aktivitas pendanaan Bank menunjukkan hubungan negatif sebesar $0,68 \%$ dengan laba setelah pajak. Ini berarti bahwa jika ada penambahan pendanaan untuk Bank akan menyebabkan menurunnya laba setelah pajak yang diperoleh Bank. (Dilipkumar \& Alkaben 2014) melakukan penelitian dengan hasil rasio perputaran persediaan yang juga termasuk indeks profitabilitas, menunjukkan jika rasio tinggi menandakan lebih banyak keuntungan, dan jika rasio rendah menandakan keuntungan rendah.

\section{METODE PENELITIAN \\ Pendekatan Penelitian}

Penelitian ini menggunakan pendekatan positivism, yaitu sebuah pendekatan penelitian yang menggunakan data kuantitatif yang dalam bentuk fakta. Alasan menggunakan pendekatan ini karena data yang digunakan adalah data yang sudah diolah oleh pihak ketiga dan dalam bentuk angka (numerik). Data yang digunakan adalah data laporan keuangan perusahaan yang sudah tersedia di Bursa Efek Indonesia (BEI) mulai tahun 2014 sampai dengan tahun 2017.

\section{Kerangka Konseptual}

Hubungan antara rasio leverage dan profitabilitas yang digunakan untuk mengukur kinerja keuangan perusahaan tampak pada Gambar 1 berikut:

Gambar 1 Kerangka Konseptual

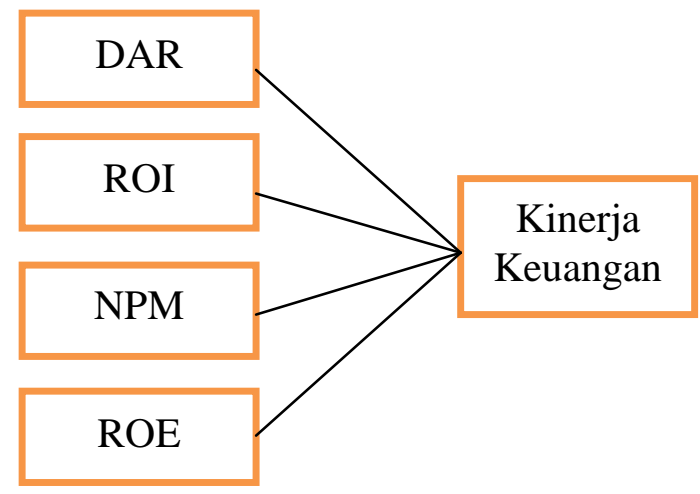

Keterangan Gambar 1:

DAR : Debt Asset Ratio

ROI : Return on Investment

NPM : Net Profit Margin

ROE : Return on Equity 


\section{Analisis Data}

Metode analisis data yang digunakan adalah metodedeskriptif kuantitatif dengan menggunakan analisis rasio keuangan. Analisis rasio keuangan yang digunakan adalah analisis leverage dan analisis profitabilitas. Rumusan analisis rasio leverage yang digunakan adalah:

$$
D A R=\frac{\text { Total Kewajiban }}{\text { Total Aktiva }}
$$

Rumusan analisis rasio profitabilitas yang digunakan adalah:

$$
\begin{gathered}
R O I=\frac{\text { Earning After Tax }(E A T)}{\text { Total asset }} \\
\text { Net Profit Margin }=\frac{\text { Laba Bersih Setelah Pajak }}{\text { Penjualan }} \times 100 \% \\
R O E=\frac{\text { Earning After Tax (EAT) }}{\text { Shareholder's Equity }}
\end{gathered}
$$

\section{HASIL PENELITIAN DAN PEMBAHASAN}

\section{Analisis Rasio Leverage}

Jika dilihat dari hasil perhitungan rasio leverage, maka dapat perusahaan menunjukkan kemampuannya dalam membayar hutanghutangnya baik jangka pendek maupun jangka panjang, karena selama jangka waktu tahun 20142017 hasil perhitungan rasio leverage menunjukkan angka yang meningkat. Ini tampak pada Tabel 1 berikut:

Tabel 1.

\begin{tabular}{|c|c|c|c|c|c|}
\hline Tahun & Total Asset & Total Hutang & Hutang Jangka Panjang & Asset Tetap & Leverage \\
\hline 2014 & $58.2 \beta 4.278$ & 25.099 .875 & 1.316 .741 & 20.936 .982 & 43,10 \\
\hline 2015 & 63.505 .413 & 25.497 .504 & 1.452 .418 & 19.701 .678 & 40,15 \\
\hline 2016 & 62.951 .634 & 23.387 .406 & 1.748 .841 & 21.018 .461 & 37,15 \\
\hline 2017 & 66.759 .930 & 24.572 .266 & 1.961 .224 & 22.995 .440 & 36,81 \\
\hline
\end{tabular}

Total Asset,Total Hutang, Hutang Jangka Panjang, Asset Tetap dan Rasio Leverage

Tahun 2014-2017 (dalam jutaan rupiah)

Sumber: BEI dan diolah tahun 2018

Tabel 1 menunjukkan bahwa hasil perhitungan analisis rasio leverage perusahaan dari tahun $2014-$ 2017 mengalami fluktuatif, yaitu sebesar 43,10\% (2014), sebesar 40,15 (2015), sebesa 37,15 (2016) dan sebesar 36,81 (2017). Rata-rata rasio leverage selama 4 tahun sebesar 39,30\%. Ini berarti bahwa selama empat tahun para kreditor telah menyediakan 39,30\% dari jumlah pembiayaan perusahaan. Grafik analisis leverage tampak pada Gambar 2 berikut:
Gambar 2

Grafik Rasio Leverage dari Tahun 2014-2017 (dalam \%)

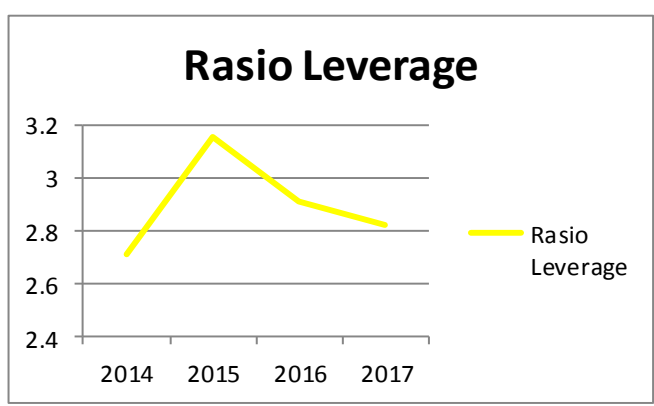

Analisis Rasio Profitabilitas

\section{Return On Investment (ROI)}

Hasil perhitungan analisis profitabilitas perusahaan selama tahun 2014-tahun 2017, dengan menggunakan pengukuran ROI tampak pada Tabel 2 berikut:

Tabel 2.

Laba Bersih, Total Asset dan ROI Tahun 20142017 (dalam jutaan rupiah)

\begin{tabular}{cccc}
\hline Tahun & Laba Bersih & Total Asset & ROI \\
\hline 2014 & 5.432 .667 & 58.234 .278 & 9,32 \\
\hline 2015 & 6.452 .834 & 63.505 .413 & 10,30 \\
\hline 2016 & 6.672 .682 & 62.951 .634 & 10,60 \\
\hline 2017 & 7.755 .347 & 66.759 .930 & 11,62 \\
\hline \multicolumn{5}{c}{ Rata-rata } & 10,46 \\
\hline
\end{tabular}

Sumber : BEI dan diolah 2018

Tabel 3 menunjukkan bahwa nilai laba bersih perusahaan dari tahun 2014 sampai dengan tahun 2017 mengalami kenaikan, dari Rp 5.432.667 juta pada tahun 2014 menjadi Rp 7.755.347 juta pada tahun 2017. Jumlah kenaikan sebesar 42,75\% selama empat tahun. Kenaikan ini dapat dikatakan menunjukkan angka yang lumayan baik bagi sebuah perusahaan dalam kondisi ekonomi yang mengalami penurunan daya beli dan adanya peringatan untuk konsumen rokok karena kesehatan. Selain itu, kenaikan ini juga disebabkan oleh karena nilai penjualan juga mengalami peningkatan, dari Rp 65.185 .850 juta (2014) menadi Rp 83.305.925 juta (2017). Peningkatan penjualan ini juga disebabkan karena peningkatan kepercayaan masyarakat terhadap produk perusahaan. Grafik NPM tampak pada Gambar 3 berikut:

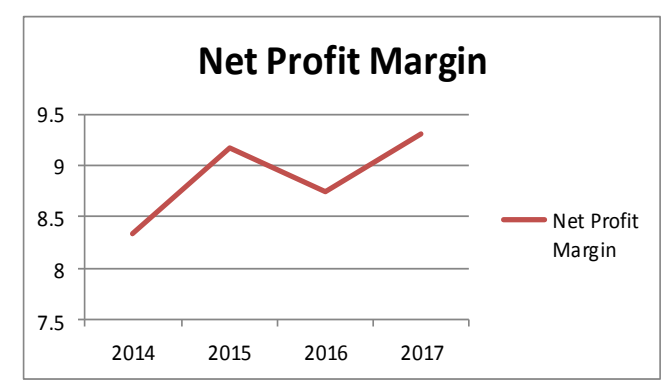




\section{Return on Equity (ROE)}

Hasil perhitungan ROE perusahaan selama tahun 2014 sampai dengan tahun 2017, tampak pada tabel 4 berikut:

Tabel 4

Laba bersih, Ekuitas dan ROE Tahun 2014-2017 (dalam jutaan rupiah)

\begin{tabular}{cccc}
\hline Tahun & Laba Bersih & Ekuitas & ROE \\
\hline 2014 & 5.432 .667 & 33.134 .403 & 16,40 \\
\hline 2015 & 6.452 .834 & 38.007 .909 & 16,98 \\
\hline 2016 & 6.672 .682 & 39.564 .228 & 16,86 \\
\hline 2017 & 7.755 .347 & 42.187 .664 & 18,38 \\
\hline \multicolumn{5}{c}{ Rata-rata } & 17,16 \\
\hline
\end{tabular}

Sumber : BEI dan diolah 2018

Tabel 4 menunjukkan bahwa selain kenaikan jumlah laba bersih yang diperoleh perusahaan mengalami peningkatan, juga menunjukkan jumlah ekuitas yang yang dimiliki oleh perusahaan juga mengalami peningkatan, yaitu sebesar Rp 33.134.403 juta (2014) menjadi Rp 42.187.664 juta (2017). Kenaikan nilai laba bersih dan ekuitas akan menyebabkan kenaikan pula pada rasio pengembalian atas modal. Artinya selama empat tahun perusahaan mampu untuk memberikan pengembalian atas modal sendiri dan modal asing sebesar 17,16\%. Grafik ROE tampak pada Gambar 4 berikut:

Gambar 3

Grafik Return On Equity (ROE) tahun 2014-2017 (dalam \%)

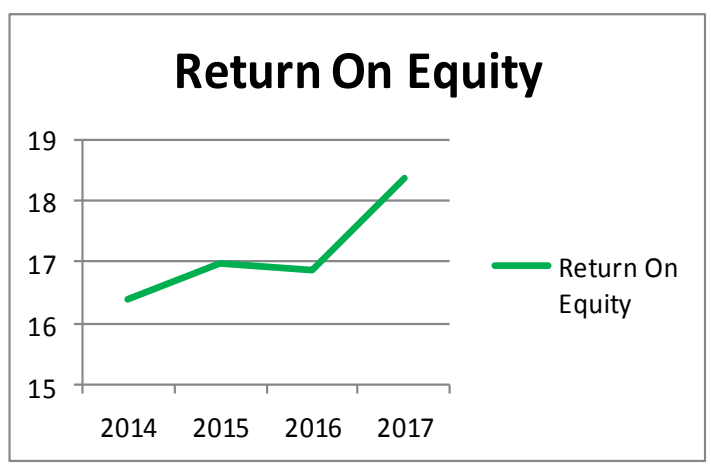

\section{Pembahasan}

\section{Analisis Rasio Leverage}

Hasil analisis leverage yang tapak pada Tabel 1 di atas menunjukkan bahwa kreditor telah menyiapkan dana untuk menggerakkan usaha perusahaan sebesar $39,30 \%$ apabila perusahaan mengalami kebangkrutan. Dilihat dari besarnya angka kesiapan dari para kreditor ini menyebabkan perusahaan bertahan untuk tetap mengembangkan usahanya dan dikatakan perusahaan dalam kondisi solvable. Hasil penelitian ini sejalan atau mendukung penelitian (Riyashad Ahmed 2001; Sultan 2014; Rosini \& Gunawan 2018; Anwar et al. 2016).

\section{Analisis Profitabilitas}

Dalam penelitian ini analisis profitabilitas perusahaan dilihat dari tiga sisi, antara lain:

1) Return on Investment (ROI)

Hasil perhitungan ROI perusahaan selama empat tahun memberikan hasil yang cukup baik, artinya kemampuan perusahaan dalam memberikan pendapatan atas investasi yang telah ditanamkan oleh para investor ratarata sebesar $10,46 \%$ dari modal yang ditanam oleh para investor. Nilai pengembalian ini dikatakan cukup baik, karena masih di atas nilai rata-rata industri, yaitu sebesar 9,20\%. Dengan angka rata-rata $10,46 \%$, ini sangat mudah bagi perusahaan untuk menarik caloncalon investor baru untuk menginvestasikan di perusaaan ini. Kondisi ini harus dipertahankan oleh perusahaan atau bahkan ditingkatkan dengan memperluas pemasaran untuk mendongkrak penjualan.

Hasil penelitian ini sejalan dengan penelitian (Adedeji 2014; Amah et al. 2016; Anwar et al. 2016).

2) Net Profit Margin (NPM)

Hasil perhitungan NPM perusahaan selama empat tahun memberikan hasil yang cukup, yaitu rata-rata sebesar $8,89 \%$. Ini berarti bahwa perusahaan dari tahun-tahun ke tahun mengalami peningkatan penjualan. Dalam kondisi krisis ekonomi (melemahnya nilai tukar rupiah terhadap dollar) tidak menyurutkan masyarakat mengkonsumsi rokok. Selain itu, juga dengan adanya peringatan dari pemerintah tentang bahaya merokok, tidak menjadi penyebab menurunnya permintaan akan rokok dari perusahaan ini. Kemampuan perusahaan dalam menjual produk dan menghasilkan laba yang cukup ini juga menjadi salah satu tolok ukur investor memilih untuk berinvestasi di perusahaan ini.

Hasil penelitian ini sejalan dengan penelitian (Rosini \& Gunawan 2018; Ganga et al. 2015; B.Batchimeg 2017).

3) Return On Equity (ROE)

Hasil perhitungan ROE perusahaan selama empat tahun memberikan hasil yang baik, yaitu rata-rata sebesar $17,16 \%$, artinya selama empat tahun perusahaan mampu untuk membayar atau mengembalikan modal baik yang berupa modal sendiri maupun modal asing. Kemampuan perusahaan ini juga menjadi salah satu tolok ukur bagi calon investor untuk menaruh uang atau modalnya pada perusahaan. Kemampuan perusahaan ini didukung oleh NPM yang cukup baik. Hasil penelitian ini tidak sejalan dengan penelitian (Tugas et al. 2012; Riyashad Ahmed 2001). 


\section{PENUTUP}

\section{Kesimpulan}

Ada beberapa hal yang dapat ditarik kesimpulan dari hasil dan pembahasan penelitian ini, antara lain: (1) Rasio-rasio yang digunakan untuk mengukur kinerja perusahaan dari sisi keuangan memberikan hasil yang baik. Artinya perusahaan dapat dikatakan dalam kondisi sehat. (2) Kondisi kesehatan perusahaan ini didukung oleh kemampuan dalam menghasilkan laba perusahaan dan kemampuan perusahaan dalam menjamin pengembalian atas hasil investasi dan modal yang telah ditanamkan oleh investor ke perusahaan. (3) Kepercayaan masyarakat terhadap produk yang dihasilkan dan dijual oleh perusahaan masih tinggi, sehingga dapat memberikan dampak positif pada kondisi keuangan perusahaan.

\section{Rekomendasi}

Rekomendasi yang dapat diberikan dari hasil penelitian ini unntuk perusahaan, antara lain: (1) perusahaan harus dapat mempertahankan kualitas produk atau bahkan bisa meningkatkan kualitas produk agar dapat tetap bersaing di pasar, (2) perusahaan harus memperluas pangsa pasar dari produk-produk yang dihasilkan baik di dalam negeri maupun di luar negeri. (3) mempertahankan manajemen yang sudah baik.

\section{Keterbatasan}

Keterbatasan dalam penelitian ini adalah (1) penelitian ini hanya dilakukan selama 4 (empat) tahun. (2) penelitian ini tidak menggunakan seluruh rasio keuangan yang ada dalam mengukur kinerja keuangan perusahaan. (3) penelitian ini hanya menggunakan analisis rasio keuangan dalam mengukur kinerja perusahaan, tidak meggabungkan antara analisis rasio keuangan dengan analisis yang lainnya.

\section{DAFTAR PUSTAKA}

Adedeji, E.A., 2014. A Tool for Measuring Organization Performance using Ratio Analysis. Research Journal of Financial and Accounting, 5(19), pp.16-23.

Amah et al., 2016. Relationship Of Cash Flow Ratios And Financial Performance. European Journal of Accounting, Auditing and Finance Reseacrh, 4(4), pp.89-97.

Anwar, K., Marliani, G. \& Indra, C., 2016. Financial Ratio Analysis for Increasing the Financial Performance of the Company at Bank Bukopin. IJSBAR, 29(2), pp.231-236.

B.Batchimeg, 2017. Financial performance measurement with the use of financial ratios : case of Mongolian companies. IJEMS, 2(3), pp.20-32.

Dilipkumar, P. \& Alkaben, P., 2014. Financial Profitability Analysis of Co-operative society of Taluk-Kaprada Patel Dilipkumar Patel Alkaben Commerce. IJSR, III(III), pp.51-53.

Ganga, M.M., Kalaiselan, M.P. \& Suriya, M.R., 2015. Evaluation of Financial Performance. IJRSP, 5(4), pp.1-7.

Riyashad Ahmed, 2001. “Financial Performance Evaluation \& Ratio Analysis of Square Toiletries Ltd .," Bangladesh. Available at: http://www.squaretoilatries.com.

Rosini, I. \& Gunawan, J., 2018. Financial Ratio and Performance Airlines Industry with DEA and TOPSIS Model. International Journal of Pure and Applied Mathematics, 119(10), pp.367-374.

SD Suindyah, 1997. [CITATION] Penggunaan rasio keuangan untuk Pengelompokkan Perusahaan dari Segi Kinerja Keuangan (Pada Industri Manufaktur yang Go Publik di $P T$. BES. Brawijaya Uiniversity.

Sultan, A.S., 2014. Financial Statements Analysis Measurement of Performance and Profitability: Applied Study of Baghdad Soft-Drink Industry. Research Journal of Finance and Accounting, 5(4), pp.49-56.

Tugas, F.C., Ramon, V. \& College, R., 2012. A Comparative Analysis of the Financial Ratios of Listed Firms Belonging to the Education Subsector in the Philippines for the Years 2009-2011., 3(21), pp.173-190.

\section{Profil Penulis}

1. Sayekti Suindah Dwiningwarni, Dosen Universitas Darul 'Ulum Jombang Email : sayekti.undar67@gmail.com

2. Judi Suharsono, Dosen Universitas Panca Marga Probolinggo.

Email : Judisuharsono@gmail.com

3. Dian Yuliana Safitri, Dosen Universitas Darul 'Ulum Jombang

Email : dianyulianas@gmail.com 